\section{AMERICAN FOSSIL CYCADS. ${ }^{1}$}

THE wonderful state of preservation of many Palæozoic plants, which has enabled us to gain much valuable information in regard to phylogenetic problems, is in marked contrast to the general absence of petrified fossils afforded by Mesozoic strata. Thanks to the ability and energy of Mr. G. R, Wieland, liberally backed by the Carnegie Institution, a flood of light has been thrown on the morphology of an extinct group of Mesozoic gymnosperms, which it is possible to study with a precision and thoroughness hardly to be surpassed in the case of recent plants. Mr. Wieland's monograph, with its splendid set of large plates, is an addition to botanical literature of exceptional importance. After reading the volume, we couple with a grateful acknowledgment of what has already been done an earnest wish that the results of further investigations may be presented in an equally attractive form in the near future.

Mesozoic plant-bearing rocks in almost all parts of the world are characterised by an abundance of pinnate fronds, recognised by Brongniart and by other pioneers of palæobotany as cycadean on account of their close agreement in external characters with those of modern cycads-a small group of tropical gymnosperms occasionally extending into subtropical regions, which constitute an unobtrusive assemblage of survivals from a remote past. Stems which might reasonably be supposed to have borne these fronds have until recently been met with in a few localities only, and never in great quantity, except, perhaps, in the Purbeck beds of Portland. As Wieland says, it is with the work of the English botanists Carruthers and Williamson (1868) that the exact investigation of fossil cycadean stems "may be said to have fairly begun." The famous species Bennettites Gibsonianus of Lower Greensand age, discovered many years ago in Luccomb Chine in the Isle of Wight, first described by Mr. Carruthers and afterwards by Prof. Graf zu Solms-Laubach, has made us familiar with the striking differences between the reproductive shoots of this extinct type and those of existing cycads, differences of surprising magnitude in view of the close resemblances as regards habit and vegetative anatomy. Other European examples of Bennettites have been described by Profs. Cappellini and Solms-Laubach, and an exceptionally well-preserved French Liassic species by Prof. Lignier, of Caen. In 1860 Philip Tyson discovered a few silicified cycadean stems in the Potomac formation of Maryland, but these were not submitted to more than a superficial examination; it was not until the last decade of the nineteenth century that the late Prof. Marsh, of Yale, with an energy worthy of a pupil of Goeppert, secured a collection of more than 700 petrified stems from the Upper Mesozoic rocks of the Black Hills of Dakota and Wyoming. European botanists who have had an opportunity of seeing some of these relics of cycadean groves of the Upper Jurassic and Lower Cretaceous periods in American museums have eagerly waited for the publication of Mr. Wieland's investigations, and the preliminary papers which he contributed to the American Journal of Science (1899-1904) served to intensify the impatience with which the more complete descriptions have been awaited.

In chapter $i$. the author gives an interesting summary of collections of cycadean stems; chapter ii. is devoted to their preservation and external characters. In chapter iii. we read of the difficulty of attacking these enormous fint-like fossils, and of the ingenuity by which the silicified trunks were made accessible to minute examination. Tubular drills were found to afford the best results ; photographs of some of the drilled stems remind one of cylindrical cheeses to which the taster's scoop has been freely applied.

Chapter iv. treats of internal structure; many of the facts recorded merely confirm what was previously known, but additional information is given in regard to the anatomy of vegetative organs which makes us wish for further details in regard to many points still left in doubt or incompletely dealt with. We should like to know more about the relative abundance of centrifugal and centripetal

1 "American Fossil Cycads" Bv G. R. Wieland. Pp. viii $+284+$ p'ates. (Publinhed by the Carnegie Institution of Washington, rgc6.) wood in the leaf-traces; we are curious to know whether the Bennettites stems usually possessed one cambium-zone or several, and it would be interesting to have more definite statements as to the histological characters of the secondary wood. It is not improbable, as $\mathrm{Mr}$. Wieland suggests, and as the writer suspected from an examination of a silicified cycadean stem from India, that these Mesozoic stems, in some cases at least, differed from modern cycads in the greater compactness and hardness of their wood. No one recognises more fully than Mr. Wieland how much remains to be done, and he promises to do his best to fill up these and other lacunæ. In chapter v. we have an exceedingly interesting account of the vernation and structure of young fronds preserved in buds on the main trunk. It is a curious fact that, despite the extra-

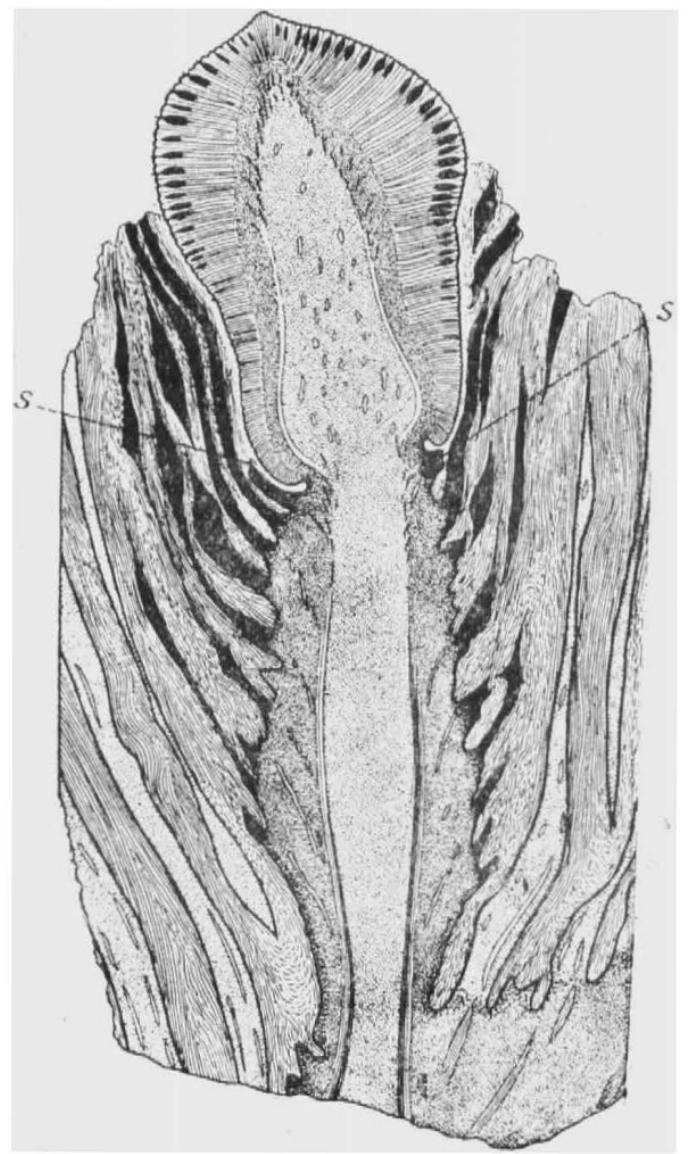

FIG. I.-Cycadeoidea Marshiana. Longitudinal section through ovulate strobilus. $s=$ remnant of dehiscent disc of microsporophylls.

ordinary abundance of stems, detached fronds have not been found in the enclosing strata, a circumstance which enhances the value of the discovery of unexpanded pinnate leaves in organic connection with the stem.

It is, however, in chapters vi. and vii. that we find by far the most important part of the author's work. The researches of Carruthers and other authors have shown that Bennettites did not bear terminal, or in some cases apparently terminal, flowers as do the true cycads, but produced axillary branches consisting of a comparatively short axis ending in a terminal receptacle crowded with two sets of appendages, slender stalks terminating in single orthotropous seeds associated with sterile organs, probably homologous with the seed-bearing pedicels, termed interseminal scales, which overtopped the small seeds and almost completely enclosed them in a protecting envelope. These axillary shoots usually occur in profusion on a single stem, and, as Wieland points out, often in approxiNO. I 944 , VOI. 75$]$ 
mately the same stage of development; it may be, as he suggests, that the plant did not fruit until reaching maturity. The seeds of Bennettites are in size like "small grains of rye"; they seem to be exalbuminous, and have little in common with the enormous seeds of recent cycads. With the exception of a single Italian species, in which Solms-Laubach found a few pollen grains associated with a female flower, we were in complete ignorance as to the nature of the male flowers until the publication of Wieland's results. It was usually assumed that in Bennettites, as in true cycads, the flowers were unisexual. Whatever interpretations we put on the morphological value of the interseminal scales and seed-bearing pedicels, it is clear that the female flowers of the fossil genus are characterised by a morphological plan far removed from

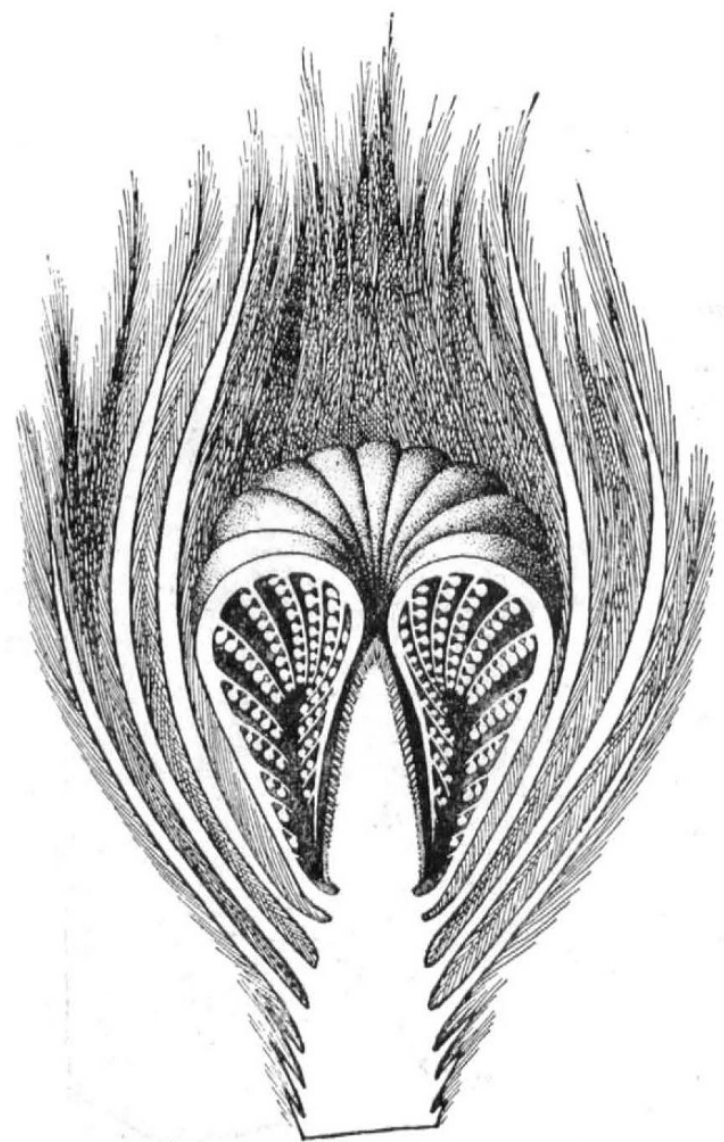

$F_{1 G}$. 2.- Restoration of unexpanded bisporangiate strobilus thowing enveloping bracts, fulded microsporophylis and conical receptacle bearing short ovuliferous pedicels, \&c.

that of the leaf-like carpels of Cycas and from the crowded carpellary scales of other recent genera.

Mr. Wieland has conclusively proved that previous views as to the unisexual character of the Bennettites flowers are incorrect; in most cases, at any rate, the flowers were bisexual. He figures several examples of reproductive shoots terminating in ovulate flowers like those of Bennettites Gibsonianus, bearing a basal rim (Fig. $\mathrm{I}, \mathrm{s}$ ) to which was formerly attached a hypogynous whorl of pinnate microsporophylls with pinnules reduced to an axis producing numerous synangia and microspores. This assumption as to the former association of microsporophylls with a central group of ovuliferous pedicels is justified by the discovery of numerous examples of bisexual flowers, consisting of an axis terminating in a conical receptacle bearing the two sets of organs characteristic of what have previously been styled female flowers, but differing in the smaller size of the seed-stalks and interseminal scales, and presenting the appearance of partially aborted or immature female organs. Surrounding this central receptacle there is a whorl of several pinnate leaves with their upper portions folded inwards between the petioles of the central gynocium (Fig. 2), and bearing rows of synangia of a type but little removed from those of modern marattiaceous ferns. No specimen has so far been described of a bisexual flower in which both androcium and gynœcium are mature. There appear to be two possible explanations: are these bisexual flowers comparable with the male flowers of Welwitschia (Tumboa), in which the female portion is functionless; or have we a case of dichogamy, in which the male organs matured first, and were subsequently shed? This discovery, first announced in a short paper by $\mathrm{Mr}$. Wieland in 1899, is of the greatest importance as demonstrating the retention in a comparatively little altered form of filicinean synangia and spores of the marattiaceous type side by side with female organs which foreshadow the angiospermous gynœcium. It is impossible in the space at our disposal to attempt to deal with the numerous questions of phylogeny-the probable line of evolution of the Bennettitales and their relationship to modern cycads-but we naturally ask, Is it fitting to speak of plants possessing this type of flower as cycads? The term cycads used by the author is perhaps justifiable if adopted in the widest sense, but the reviewer cannot help feeling in sympathy with a view expressed in a letter recently received by him from Prof. Nathorst, of Stockholm, that the extension of the designation cycads to plants so far removed in the organisation of their essential organs from the cycads as we know them necessarily tends to minimise the importance of fundamental differences.

The generic name Cycadeoidea, proposed by Buckland in 1827 , is used by the author in preference to Carruthers's genus Bennettites; it would, we think, be better to retain the latter name for all cycad-like stems possessing the lateral fertile shoots of the type originally described by Mr. Carruthers. There is another very different form of stem which Nathorst discovered in the Rhatic plant beds of Scania bearing fronds long known as a species of Anomozamites, and flowers which probably agreed closely with those of Bennettites. This stem, which Nathorst names Williamsonia angustifolia, is important as demonstrating the wide range of vegetative variation within the great group Cycadophyta. The discoveries of $\mathrm{Mr}$. Wieland, Prof. Nathorst and others demonstrate the impossibility of forming any adequate conception of the nature of the Cycadophyta - to use Nathorst's convenient term-if we confine our attention to the meagre remnant of that phylum which has survived the revolutions in the plant kingdom since the beginning of the Cretaceous era.

In the concluding chapters $\mathrm{Mr}$. Wieland deals with questions of phylogeny; while recognising much that is suggestive in the treatment of this difficult subiect, we feel that there is a certain vagueness in his conclusions which, though partly due to lack of data, is perhaps to some extent the result of a want of clearness and conciseness of treatment. The initial difficulties have, however, been surmounted, and $\mathrm{Mr}$. Wieland has completed with conspicuous success a very important section of the work; we close the volume with a desire for more, and heartily wish the author further success in a field where the opportunities are unrivalled.

A. C. S.

\section{THE RECENT HIGH BAROMETER.}

A REGION of exceptionally high barometer readings over western Europe was a feature of especial interest during a great part of January, the mercury in many places attaining to a greater height than any previous record, while elsewhere the readings have scarcely been exceeded. To trace the history of this anticyclonic region and to attempt any explanation requires a series of synchronous and synoptic charts embracing a large part of the northern hemisphere; possibly this may be undertaken by one of our European weather offices when all the facts have been collated. It would seem that vessels traversing the Atlantic have in many cases pxperienced

NO. I 944, VOL. 75] 